\title{
PENGARUH BUDAYA ORGANISASI, GAYA KEPEMIMPINAN, DAN LINGKUNGAN KERJA FISIK TERHADAP DISIPLIN KERJA KARYAWAN
}

\author{
Putu Angga Armawan' \\ I Wayan Suana ${ }^{2}$ \\ 1,2 Fakultas Ekonomi dan Bisnis Universitas Udayana (Unud), Bali, Indonesia \\ E-mail:jatiluwih21@gmail.com
}

\begin{abstract}
ABSTRAK
Disiplin kerja ialah suatu cara yang digunakan suatu perusahaan untuk mempengaruhi tingkah laku karyawannya agar taat terhadap ketentuan dan aturan dalam perusahaan untuk mencapai tujuan yang dimiliki perusahaan. Disiplin kerja dipengaruhi oleh budaya organisasi, gaya kepemimpinan, dan lingkungan kerja fisik. Tujuan penelitian ini adalah untuk mengetahui pengaruh budaya organisasi, gaya kepemimpinan, dan lingkungan kerja fisik terhadap disiplin kerja karyawan UPT. Balai Latihan Kerja Industri Dan Pariwisata Bali.Penelitian ini dilakukan di UPT. Balai Latihan Kerja Industri Dan Pariwisata Bali. Jumlah sampel yang diambil sebanyak 40 orang termasuk kepala Dinas, dengan metode sampling jenuh. Pengumpulan data dilakukan melalui wawancara dan kuisioner. Teknik analisis yang digunakan adalah regresi linier berganda.Berdasarkan hasil analisis ditemukan bahwa budaya organisasi, gaya kepemimpinan, dan lingkungan kerja fisik berpengaruh signifikan terhadap disiplin kerja.
\end{abstract}

Kata kunci: disiplin kerja, budaya organisasi, gaya kepemimpinan, lingkungan kerja fisik

\begin{abstract}
Work discipline is a method used by a company to influence the behavior of its employees in order to obey the rules and regulations in the company to achieve the goals of the company. Work discipline is influenced by organizational culture, leadership style, and physical work environment. The purpose of this study was to determine the effect of organizational culture, leadership style, and physical work environment on the work discipline of UPT employees. Bali Industrial and Tourism Training Center. This research was conducted at the UPT. Bali Industrial and Tourism Training Center. The number of samples taken was 40 people including the head of the Office, with a saturated sampling method. Data collection is done through interviews and questionnaires. The analysis technique used is multiple linear regression. Based on the results of the analysis it was found that organizational culture, leadership style, and physical work environment had a significant effect on work discipline.

Keywords: work discipline, organizational culture, leadership style, physical work environment
\end{abstract}




\section{PENDAHULUAN}

Manusia sebagai aktor utama dalam kegiatan organisasi merupakan aset yang unik, karena dalam pengelolaannya begitu banyak faktor yang mempengaruhinya dan sulit untuk diprediksi, hal tersebut tentunya akan mempengaruhi pencapaiandisiplin kerja dari setiap karyawan. Mengingat sumber daya manusia merupakan harta atau aset yang paling berharga dan paling penting maka setiap organisasi harus mampu mengatur proses pemanfaatan sumber daya manusia yang dimiliki guna kelangsungan hidup organisasi. Menciptakan sumber daya manusia yang berkualitas perlu adanya pembinaan disiplin kerja dalam tiap diri karyawan pada organisasi yang merupakan tindakan manajemen untuk mendorong para anggotanya untuk memenuhi berbagai ketentuan (Iswara dan Sudharma, 2013).

Disiplin adalah sikap seseorang untuk mematuhi dan mentaati segala macam norma-norma peraturan yang berlaku disekitarnya, sedangkan kedisiplinan adalah kesadaran dan kesediaan seseorang untuk mentaati semua peraturan persahaan dan norma-norma sosial yang berlaku (Hasibuan, 2009). Organisasi harus melakukan pengawasan guna mengontrol disiplin kerja karyawan sehari-hari, karena tingkat disiplin kerja akanberdampak positif pada pencapaian tujuan organisasi tersebut.

Budaya organisasi merupakan nilai-nilai, prinsip, tradisi dan cara-cara bekerja yang dianut bersama oleh para anggota organisasi dan memengaruhi cara mereka bertindak (Robbins, 2010). Budaya organisasi memberikan identitas pada anggotanya untuk berperilaku sesuai prinsip dan nilai organisasi. Apabila prinsip dan nilai perusahaan dapat dimaknai dan dipahami anggota organisasi dengan 
baik dan benar, maka akan terwujud perilaku yang sejalan dengan prinsip nilai organisasi, sehingga muncul perilaku disiplin kerja yang baik pada anggota organisasi.

Budaya organisasi di setiap perusahaan berbeda-beda, budaya organisasi dapat mempengaruhi tingkah laku dari anggota organisasi tersebut. Dengan demikian pemimpin dapat mempengaruhi bawahannya melalui budaya organisasi. Ini berarti terjadi komitmen yang saling mendukung antara budaya organisasi dan pimpinan dalam mempengaruhi kinerja karyawan suatu perusahaan atau organisasi.

Budaya organisasi yang diterapkan oleh karyawan UPT. BLK Industri dan Pariwisata Bali adalah integritas, profesional, keselamatan, inovasi, dan pelayanan prima. Budaya organisasi mempengaruhi disiplin kerja karyawan. Menurut Dwitya dan Mahendra (2014) menyatakan bahwa budaya organisasi sangat mempengaruhi perilaku karyawan, budaya organisasi yang kuat akan berpengaruh terhadap pembentukan perilakuanggota-anggotanya, yang kemudian akan menjadikan budaya dalam suatu organisasi tersebut. Budaya organisasi terdiri dari dimensi lapisan bertingkat yaitu lapisan terlihat atau visible artifacts dan lapisan tak terlihat atau invicible artifacts (Daft, 2010). Invisible artifacts dalam dimensi budaya organisasi merupakan suatu sistem nilai yang berperan dalam terbentuknya sikap dan perilaku anggota organisasi. Hal tersebut dikarenakan sistem nilai merupakan wujud dari nilai-nilai pokok suatu organisasi yang mengarahkan anggota organisasi mewujudkan goal, visi, misi dan tujuannya (Schein, 2004). Hal tersebut artinya bahwa sistem nilai merupakan nilai-nilai 
pokok organisasi yang diyakini anggota organisasi sehingga mengarahkan anggota organisasi untuk bekerja sesuai peraturan dan standar perusahaan. Sikap dan perilaku seseorang yang bekerja sesuai standar perusahaan dan mematuhi peraturan merupakan wujud dari sikap dan perilaku disiplin kerja. Keengganan untuk menggunakan disiplin ini juga sampai kepada PHK karyawan bermasalah.

Kepemimpinan mempunyai pengaruh yang sangat erat dengan budaya organisasi, karena seorang pemimpin akan membentuk budaya organisasi yang nantinya akan menentukan keberhasilan seorang pemimpin dalam menggerakan bawahannya dalam mencapai tujuan. Yukl (2010) mengatakan kepemimpinan didefinisikan sebagai proses mempengaruhi orang lain untuk mengenali dan setuju tentang apa yang perlu dilakukan dan bagaimana melakukannya, dan proses memfasilitasi upaya individudan kolektif untuk mencapai tujuan bersama. Gaya kepemimpinan adalah cara seorang pemimpin dalam mempengaruhi orang lain untuk mengenali apa yang perlu dilakukan dan bagaimana melakukannya. Hesselbein dan Cohen (1999) menyarankan bahwa organisasi kini berkembang menuju struktur yang tanggung jawab tetapi tidak otoritas dan dimana pekerjaan pemimpin tidak memerintah tetapi membujuk. Gaya kepemimpinan yang tepat merupakan tantangan bagi kebanyakan perusahaan yang beroperasi pada perubahan dunia yang cepat dan kebutuhan untuk terus mengembangkan potensi sumber daya manusia (Woszczyna, 2015). Pemimpin yang sesungguhnya mempengaruhi hasil (Stephen dan Barry Stemshorn, 2016). Siagian dalam Baihaqi (2010) menyatakan ada lima tipe gaya kepemimpinan yaitu tipe otokratis, tipe militeritis, tipe paternalistis, tipe karismatis, dan tipe demokratis. Gaya 
kepemimpinan dapat diukur dengan indikator perilaku instruktif perilaku konsultatif, perilaku partisipatif, perilaku delegatif, kepemimpinan direktif, kepemimpinan suportif dan kepemimpinan yang berorientasi pada prestasi (Thoha, 2007). Keberhasilan seorang manajer atau pemimpin dalam memimpin orang dinilai dari kinerja dan hasil tim (Mohelska, 2015). Pemimpin sangat berperan dalam menentukan keberhasilan suatu perusahaan, perusahaan dikatakan berhasil apabila mampu meningkatkan peran serta aktif dari karyawan. Meningkatkan peran serta keaktifan karyawan, memerlukan lingkungan kerja fisik yang dapat meningkatkan gairah serta semangat kerja karyawan.

Faktor lingkungan kerja bisa berupa kondisi fisik kantor yang meliputi penerangan, suhu udara, dll yang mampu meningkatkan suasana kondusif dan semangat kerja serta berpengaruh terhadap kineria karyawan. (Dhermawan dkk., 2012). Tohadi (2002:137) menyatakan bahwa yang termasuk ke dalam lingkungan kerja fisik adalah kondisi ruangan, penerangan, gangguan dalam ruangan, keadaan udara, warna, dan kebersihan.Lingkungan keria fisik juga dapat mempengaruhi karyawan dalam melaksanakan aktivitasnya dalam bekerja. Lingkungan kerja yaitu segala sesuatu yang ada di sekitar pekerjaan, yang dapat mempengaruhi dirinya dalam mejalankan tugas (Dhermawan dkk., 2012).

Penciptaan lingkungan kerja yang baik juga akan membantu memelihara kondisi fisik sehingga kesegaran fisik karyawan terjaga, tidak lekas capek, tidak lesu dalam bekerja dan dapat bekerja lebih lama. Kondisi fisik karyawan yang terjaga ini membuat karyawan mempunyai mental yang baik (tidak stress atau tegang, tidak tertekan, tidak bosan). Lingkungan kerja mempengaruhi disiplin 
kerja karyawan, semakin baik lingkungan kerja yang disediakan perusahaan, maka akan semakin tinggi pula tingkat disiplin kerja karyawan yang berarti semakin tinggi pula tingkat keberhasilan perusahaan atau organisasi (Sukma, 2013). Martoyo (2009) dan penelitian terdahulu (Iswara dan Sudharma,2013; Sugiyatmi dkk., 2016) menyimpulkan gaya kepemimpinan dan lingkungan kerja fisik dapat meningkatkan disiplin kerja.

Tabel 1.

Absensi UPT. BLK-IP Bali

\begin{tabular}{|c|c|c|c|c|c|c|}
\hline Bulan & $\begin{array}{l}\text { Jumlah } \\
\text { Karyawan }\end{array}$ & $\begin{array}{l}\text { Jumlah } \\
\text { Hari } \\
\text { Kerja } \\
\text { Efektif }\end{array}$ & $\begin{array}{l}\text { Jumlah Hari } \\
\text { Kerja } \\
\text { Efektif/Minggu }\end{array}$ & $\begin{array}{l}\text { Total } \\
\text { Absensi }\end{array}$ & $\begin{array}{l}\text { Jumlah } \\
\text { Hari } \\
\text { Kerja } \\
\text { Terpenuhi } \\
\text { per bulan }\end{array}$ & $\begin{array}{l}\text { Persentase } \\
\text { (Total Absen : } \\
\text { Jumlah Hari } \\
\text { Kerja } \\
\text { Efektif/Minggu } \\
\text { x 100\%) }\end{array}$ \\
\hline Februari & 39 & 20 & 780 & 25 & 733 & $3.2 \%$ \\
\hline Maret & 39 & 20 & 780 & 29 & 751 & $3.7 \%$ \\
\hline Total & & 40 & 1560 & 54 & 1506 & $6.9 \%$ \\
\hline Rata- & & & & & & $3.45 \%$ \\
\hline Rata & & & & & & \\
\hline
\end{tabular}

Tabel 1. absensi UPT. BLK-IP Bali menunjukan tingkat absensi karyawanDinas Tenaga Kerja dan Energi Sumber Daya Mineral UPT. Balai Latihan Kerja Industri dan Pariwisata Bali sebagai salah satu indikasi tingkat disiplin karyawan. Berdasarkan Tabel 1 dapat disimpulkan rata-rata tingkat absensi karyawan bulan Februari dan Maret 2018 yaitu persentase 3,45. Absensi 0 sampai dengan 2 persen dinyatakan baik, 3 persen sampai dengan 10 persen dinyatakan tinggi, dan diatas 10 persen dinyatakan tidak wajar (Flippo, 2001:281). Kemangkiran karyawan tanpa alasan merupakan keadaan yang merugikan instansi. Rata-rata absensi diatas 3 persen merupakan tingkat absensi dinyatakan tinggi dan salah satu indikasi adanya masalah yang terjadi di tingkat kedisiplinan karyawan (Jaya dan Adnyani, 2015). 
UPT. BLK Industri dan Pariwisata Bali adalah Lembaga Pelatihan Kerja milik Pemerintah Provinsi Bali yang tugas utamanya memberikan pelatihan dan keterampilan kepada pencari kerja, yang berlokasi di Jl. Raya Puputan Niti Mandala Renon.Berdasarkan data yang diperoleh tingkat disiplin kerja karyawan di UPT. BLK Industri dan Pariwisata Bali masih rendah. Contoh pada saat jam kerja terlihat jarang adanya pembagian waktu dinas keluar untuk beberapa karyawan atau dapat dikatakan jarang adanya yang menjaga kantor sehingga masyarakat yang datang ke kantor bertujuan untuk menanyakan keperluan mereka, harus pulang dengan tangan kosong. Hal ini terjadi bisa dikarenakan kurangnya pengawasan pimpinan sehingga sebagian karyawan bekerjatidak sesuai peraturan, juga masih adanya absen tanpa keterangan, serta masihadanya karyawan datang diatas pukul 07.30 WITA dan pulang sebelum pukul 15.30 WITA, hal tersebut terjadi bisa dikarenakan kurang mendukungnya suasana ruangan untuk melakukan pekerjaan sehari-hari.

Oleh karena itu, berdasarkan pemaparan di atas mengenai permasalahan yang ditemukan di UPT. BLK Industri dan Pariwisata Bali dan faktor-faktor yang dapat memengaruhi displin kerja, maka penelitian ini dilakukan untuk mengetahui apakah terdapat pengaruh budaya organisasi, gaya kepemimpinan, dan lingkungan kerja fisik terhadap dispilin kerja karyawan di UPT. BLK Industri dan Pariwisata Bali.

Disiplin kerja ialah suatu alat atau cara yang digunakan suatu perusahaan untuk mempengaruhi tingkah laku karyawannya agar taat terhadap ketentuan dan aturan dalam perusahaan untuk mencapai tujuan yang dimiliki perusahaan (Rivai, 
2009 : 825). Kheruniah (2013) menyatakan bahwa, disiplin merupakan suatu kondisi penting yang menunjukkan nilai-nilai ketaatan, kepatuhan, kesetiaan, ketenteraman, keteraturan dan ketertiban karena dengan adanya pendisiplinan dari seluruh anggota organisasi maka suatu organisasi dapat mencapai tujuan organisasi tersebut. Maka sangat penting bila adanya suatu disiplin kerja karyawan di dalam suatu perusahaan. Disiplin seorang karyawan dapat dilakukan melalui berbagai cara, yang mana nantinya akan meningkatkan prestasi karyawan tersebut.

Disiplin kerja merupakan proses berperilaku pada peraturan-peraturan yang ditetapkan perusahaan, baik yang ditulis maupun tidak ditulis serta tidak mengelak dalam menerima sanksi (Mills dan Goos, 2007). Wahyudin dan Parlinda (2008), memaparkan bahwa gaya kepemimpinan berpengaruh terhadap disiplin kerja karyawan. Disiplin kerja diukur dengan (1) ketepatan waktu kerja, (2) mengikuti cara kerja perusahaan, dan (3) tanggung jawab terhadap kerja.

Disiplin yang baik mencerminkan besarnya tanggung jawab karyawan terhadap tugas-tugas yang diberikan. Disiplin lebih banyak bersumber dari dalam diri karyawan itu sendiri yang diperlihatkan dalam bentuk mematuhi peraturan yang ada di dalam perusahaan, menyelesaikan tugas tepat waktu. Untuk memelihara dan menegakkan disiplin yang baik ada banyak yang mempengaruhinya diantaranya adalah kesejahteraan, pendidikan dan pelatihan, motivasi, kepemimpinan, budaya organisasi dan lingkungan kerja (Martoyo,2002:165). Disiplin kerja ialah suatu alat atau cara yang digunakan suatu perusahaan untuk mempengaruhi tingkah laku karyawannya agar taat 
terhadap ketentuan dan aturan dalam perusahaan untuk mencapai tujuan yang dimiliki perusahaan (Rivai, 2009:825). Dalam penelitian ini diplilih tiga faktor yang mempengaruhi disiplinkerja yaitu : budaya organisasi, gaya kepemimpinan, dan lingkungan kerja fisik. Faktor-faktor tersebut diharapkan dapat meningkatkan disiplin kerja karyawan dalam mencapai tujuan perusahaan. Tindakan disiplin hendaknya bersikap positif, bukan tindakan negatif yang menjatuhkan karyawan yang berbuat salah karena disiplin bertujuan untuk memperbaiki kegiatan dimasa yang akan datang bukan menghukum kegiatan dimasa lalu.

Robbins dan Judge (2008:225) budaya organisasi adalahsistem makna bersama yang dianut oleh anggota-anggota yangmembedakan organisasi itu dari organsisasi-organisasi lain. SedangkanMoorhead (1995:246), budaya organisasi diartikan sebagai, seperangkatnilai yang diterima selalu benar, yang membantu seseorang dalamorganisasi untuk memahami tindakan-tindakan mana yang dapat diterimadan tindakan mana yang tidak dapat diterima dan nilai-nilai tersebutdikomunikasikan melalui cerita dan cara-cara simbolis lainnya.Berdasarkan definisi diatas dapat disimpulkan bahwa budaya organisasisesungguhnya tumbuh karena diciptakan dan dikembangkan olehindividu yang bekerja dalam suatu organisasi, dan diterima sebagai nilainilaiyang harus dipertahankan dan diturunkan kepada setiap anggotabaru.

Robbins (2010) menjelaskan budaya organisasi merupakan nilai-nilai, prinsip, tradisi dan cara-cara bekerja yang dianut bersama oleh para anggota organisasi dan memengaruhi cara mereka bertindak. Budaya organisasi terdiri dari nilai-nilai dominan yang didukung oleh organisasi atau falsafah yang menuntun 
kebijaksanaan organisasi terhadap karyawan dan pelanggaran, atau cara pekerjaan yang dilakukan di tempat kerja, serta asumsi maupun kepercayaan yang terdapat pada anggota organisasi.

Penelitian sebelumnya yang dilakukan Brahmasari (2009) mengenai hubungan budaya organisasi dan disiplin kerja menunjukkan bahwa budaya organisasi yang diterapkan oleh karyawan memberikan pengaruh terhadap meningkatnya sikap dan perilaku disiplin kerja karyawan. Dalam penelitiannya tersebut dijelaskan bahwa budaya organisasi yang terdiri dari nilai-nilai dan implementasi dari visi misi perusahaan yang diterapkan karyawan memberikan pengaruh terhadap meningkatnya disiplin kerja dan kinerja karyawan.

Suniastuti dan Suana (2012) dalam penelitiannya menemukan bahwa budaya organisasi berpengaruh positif dan signifikan terhadap disiplin kerja. Penelitian Iswara dan Sudharma (2013) juga menemukan bahwa budaya organisasi berpengaruh positif dan signifikan terhadap disiplin kerja.Hadyan dan Lies Endarwati (2016) dalam penelitiannya menemukan bahwa adanya pengaruh budaya organisasi terhadap tingkat disiplin kerja.

$\mathrm{H}_{1}$ : Terdapat pengaruh positif dan signifikan antara budaya organisasi dan disiplin kerja.

Beverly et al. (2008) dalam penelitiannya menjelaskan bahwa keterlibatan pemimpin dalam berkreatifitas dapat meningkatkan aturan standar kerja (dapat dikatakan sebagai disiplin kerja) yang berarti pula meningkatkan produktivitas kerja. Martoyo (2009) bahwa gaya kepemimpinan salah satu faktor yang mempengaruhi disiplin kerja karyawan. Bimbingan pemimpinan akan mampu meningkatkan tujuan organisasi dan untuk meningkatkan evektifitas kerja 
karyawan (Mahdi et al., 2004). Penelitian Ancok (2005), Suniastuti dan Suana, (2012), Susanty dan Baskoro, Sigit Wahyu (2012), Iswara dan Sudharma (2013), Ramli (2013), Sutarmaningtyas (2014), Cahyantara dan Subudi, (2015), Jaya danAdnyani, (2015), serta Sugiyatmi dkk. (2016) menemukan bahwa gaya kepemimpinan berpengaruh positif dan signifikan terhadap disiplin kerja.

$\mathrm{H}_{2}$ : Terdapat pengaruhpositif dan signifikan antara gaya kepemimpinan dengan disiplin kerja.

Martoyono (2009) bahwa lingkungan kerja fisik salah satu faktor yang mempengaruhi disiplinkerja karyawan. Menciptakan lingkungan karyawan,memfasilitasi dukungan psikologis karyawan (Hernandez et al., 2011). Khuong dan Le $\mathrm{Vu}$ (2014) menunjukan bahwa karyawan yang merasa nyaman tentang lingkungan kerja mereka cenderung bekerja lebih efektif dan menikmati proses kerja dibandingkan dengan mereka yang merasa tidak nyaman. Penelitian Andriani (2010), Iswara dan Sudharma (2013), Endriawan (2014), Marwanto dan Riyadi Nugroho (2014), serta Sugiyatmidkk. (2016) menemukan bahwa lingkungan kerja fisik berpengaruh positif dan signifikan terhadap disiplin kerja.

$\mathrm{H}_{3}$ : Terdapat pengaruh positif dan signifikan antara lingkungan kerja fisik dengan disiplin kerja.

\section{METODE PENELITIAN}

Penelitian ini dilaksanakan di UPT. BLK Industri dan Pariwisata Bali yang berlokasi di Jl. Raya Puputan Niti Mandala Renon. Lokasi ini dipilih karena ditemukan masalah-masalah mengenai budaya organisasi, gaya kepemimpinan, lingkungan kerja fisik yang menyebabkan disiplin kerja karyawan menurun. Dalam penelitian ini yang menjadi obyek penelitian adalah pengaruh budaya 
organisasi, gaya kepemimpinan, lingkungan kerja fisik, dan disiplin kerja karyawanpada UPT. BLK Industri dan Pariwisata Bali.Penelitian ini dilakukan kepada karyawan di UPT. BLK Industri dan Pariwisata Bali, tetapi tidak termasuk pemimpin perusahaan. Penelitian ini hanya membahas sumber daya manusia, khususnya pada disiplin kerja karyawan.

Populasi dalam penelitian ini adalah seluruh karyawanUPT. BLK Industri dan Pariwisata Bali yang berjumlah 40 orang. Peneliti memakai seluruh karyawan tetap yang berjumlah 39 orang tidak terhitung kepala dinas dengan menggunakan metode penentuan sampel yaitu teknik sampel jenuh atau cara sensus yang respondennya seluruh karyawan.

Teknik analisis data yang digunakan penelitian ini adalah metode regresi linier berganda. Persamaan model regresinya sebagai berikut:

$$
\mathrm{Y}=\alpha+\beta_{1} \mathrm{X}_{1}+\beta_{2} \mathrm{X}_{2}+\beta_{3} \mathrm{X}_{3}+\mathrm{e}
$$

Keterangan:

$$
\begin{array}{ll}
\mathrm{Y} & =\text { Disiplin kerja } \\
\alpha & =\text { Nilai konstanta } \\
\mathrm{X}_{1} & =\text { Budaya organisasi } \\
\mathrm{X}_{2} & =\text { Gaya Kepemimpinan } \\
\mathrm{X}_{3} & =\text { Lingkungan Kerja Fisik } \\
\mathrm{e} & =\text { Variabel pengganggu yang berpengaruh terhadap Y tetapi tidak } \\
& \text { dimasukkan dalam model. }
\end{array}
$$

\section{HASIL DAN PENELITIAN}

Berdasarkan data dari 39 responden UPT. BLK Industri dan Pariwisata Bali, karakteristik responden dilihat dari beberapa kriteria, yaitu usia, jenis kelamin, pendidikan, dan masa kerja. Karakteristik responden diuraikan sebagai berikut. 
Tabel 2.

Responden Berdasarkan Usia

\begin{tabular}{lll}
\hline Usia & Jumlah (orang) & Persentase (\%) \\
\hline $20-30$ tahun & 25 & 64,1 \\
$31-40$ tahun & 12 & 30,8 \\
$41-50$ tahun & 2 & 5,1 \\
Total & 39 & 100 \\
\hline Sumber: Data diolah, 2018 & &
\end{tabular}

Tabel 2. menunjukkan kelompok usia dominan adalah pada usia 20-30 tahun dengan persentase 64,1 persen, sedangkan untuk kelompok usia yang terendah adalah pada usia 41-50 tahun dengan persentase 5,1 persen. Kelompok usia 20-30 tahun merupakan usia produktif sehingga sesuai dengan kebutuhan UPT. BLK Industri dan Pariwisata Bali.

Tabel 3.

Responden Berdasarkan Jenis Kelamin

\begin{tabular}{lll}
\hline Jenis Kelamin & Jumlah (orang) & Persentase (\%) \\
\hline Laki-Laki & 23 & 59 \\
Perempuan & 16 & 41 \\
Total & 39 & 100 \\
\hline
\end{tabular}

Sumber: Data diolah, 2018

Tabel 3. menunjukkan persentase laki-laki sebanyak 59 persen dan perempuan sebanyak 41 persen.

Tabel 4.

Responden Berdasarkan Pendidikan

\begin{tabular}{lll}
\hline Pendidikan & Jumlah (orang) & Persentase (\%) \\
\hline SMA & 0 & 0 \\
D3 & 2 & 5,1 \\
S1 & 37 & 94,9 \\
S2 & 0 & 0 \\
Total & $\mathbf{3 9}$ & $\mathbf{1 0 0}$ \\
\hline
\end{tabular}

Sumber:Data diolah, 2018

Tabel 4. menunjukkan bahwa responden yang dominan berdasarkan pendidikan adalah pada tingkat pendidikan S1 dengan persentase 94,9 persen, sedangkan yang terendah adalah pada tingkat pendidikan D3 dengan persentase 
5,1 persen. Hal ini menunjukkan bahwa UPT. BLK Industri dan Pariwisata Bali membutuhkan karyawan yang memiliki skill, pendidikan, dan keahlian di bidangnya.

Tabel 5.

Responden Berdasarkan Masa Kerja

\begin{tabular}{lll}
\hline Masa Kerja & Jumlah (orang) & Persentase (\%) \\
\hline$<1$ tahun & 2 & 5,1 \\
$1-2$ tahun & 14 & 35,9 \\
$3-5$ tahun & 20 & 51,3 \\
$>5$ tahun & 3 & 7,7 \\
Total & $\mathbf{3 9}$ & $\mathbf{1 0 0}$ \\
\hline Sul
\end{tabular}

Sumber:Data diolah, 2018

Tabel 5. menunjukkan bahwa responden yang dominan berdasarkan masa kerjaadalah masa kerja selama 3-5 tahun dengan persentase 51,3 persen, sedangkan yang terendah adalah pada masa kerja selama kurang dari 1 tahun dengan persentase 5,1 persen. Hal ini menunjukkan bahwa UPT. BLK Industri dan Pariwisata Bali diisi oleh sumber daya manusia yang berpengalaman.

Uji normalitas ini bertujuan untuk mengetahui apakah residual dari model regresi yang dibuat berdistribusi normal atau tidak. Dalam penelitian ini uji normalitas dilakukan dengan menguji normalitas residual dengan menggunakan uji Kolmogorov-Smirnov. Jika probabilitas signifikansi nilai residual lebih besar dari 0,05 maka data tersebut dikatakan berdistribusi normal. Demikian pula sebaliknya, jika probabilitas signifikansi residual lebih rendah dari 0,05 maka data tersebut dikatakan tidak berdistribusi normal.

Berdasarkan hasil analisis pada Tabel 5didapat nilai signifikansi sebesar 0,913 yang lebih besar dari 0,05. Oleh karena nilai signifikansi uji Kolmogorov- 
Smirnov lebih dari 0,05 maka dapat disimpulkan bahwa model persamaan regresi tersebut berdistribusi normal.

Tabel 6.

Hasil Uji Normalitas

\begin{tabular}{llr}
\hline & & Unstandardized Residual \\
\hline $\mathrm{N}$ & & 39 \\
Normal Parameters ${ }^{\mathrm{a}, \mathrm{b}}$ & Mean & .0000000 \\
& Std. Deviation & 1.44996956 \\
Most Extreme Differences & Absolute & .090 \\
& Positive & .063 \\
& Negative & -.090 \\
Kolmogorov-Smirnov Z & & .560 \\
Asymp. Sig. (2-tailed) & & .913 \\
\hline Sumber: Data diolah, 2018 & &
\end{tabular}

Uji multikolinearitas bertujuan untuk menguji apakah dalam satu model regresi ditemukan adanya korelasi antar variabel bebas. Model regresi yang baik adalah tidak terjadi korelasi diantara variabel bebas. Untuk mendeteksi ada atau tidaknya korelasi antar variabel bebas dapat dilihat dari nilai tolerance dan nilai variance inflation factor (VIF). Jika nilai tolerance lebih dari $10 \%$ atau VIFKurang dari 10, maka dapat dikatakan model telah bebas dari multikolinearitas.

Tabel 7. Hasil Uji Multikoleniaritas

\begin{tabular}{cccc}
\hline Variabel & Tolerance & VIF & Keterangan \\
\hline Budaya organisasi $\left(\mathrm{X}_{1}\right)$ & 0,599 & 1,669 & Bebas multikol \\
Gaya kepemimpinan $\left(\mathrm{X}_{2}\right)$ & 0,709 & 1,410 & Bebas multikol \\
Lingkungan kerja fisik $\left(\mathrm{X}_{3}\right)$ & 0,625 & 1,600 & Bebas multikol \\
\hline Sumber: Data diolah, 2018 & & &
\end{tabular}

Berdasarkan Tabel 7. dapat dilihat bahwa nilai tolerance dan VIF dari seluruh variable tersebut menunjukkan bahwa nilai tolerance untuk setiap variabel lebih besar dari $10 \%$ dan nilai VIF lebih kecil dari 10 yang berarti model persamaan regresi bebas dari multikolinearitas. 
Uji heteroskedastisitas ini bertujuan untuk mengetahui apakah dalam model regresi terjadi ketidaksamaan varians dari residual satu pengamatan ke pengamatan lain yang dilakukan dengan uji Glejser. Model regresi yang baik adalah yang tidak mengandung gejala heteroskedastisitas atau mempunyai varians yang homogen. Jika variabel bebas yang diteliti tidak mempunyai pengaruh signifikan atau nilai signifikansinya lebih dari 0,05 terhadap nilai absolute residual, berarti model regresi tidak mengandung gejala heteroskedastisitas. Hasil pengujian heteroskedastisitas disajikan pada Tabel 8 berikut.

Tabel 8.

Hasil Uji Heteroskedastisitas

\begin{tabular}{|c|c|c|c|c|c|}
\hline \multirow[t]{2}{*}{ Model } & \multicolumn{2}{|c|}{$\begin{array}{l}\text { Unstandardized } \\
\text { Coefficients }\end{array}$} & \multirow{2}{*}{$\begin{array}{c}\text { Standardized } \\
\text { Coefficients } \\
\text { Beta } \\
\end{array}$} & \multirow[b]{2}{*}{$\mathbf{T}$} & \multirow[b]{2}{*}{ Sig. } \\
\hline & B & Std. Error & & & \\
\hline $1 \quad$ (Constant) & 3.751 & 1.014 & & 3.699 & .001 \\
\hline Budaya organisasi & -.007 & .038 & -.035 & -.175 & .862 \\
\hline Gaya kepemimpinan & -.084 & .050 & -.308 & -1.685 & .101 \\
\hline Lingkungan kerja fisik & -.029 & .039 & -.143 & -.736 & .467 \\
\hline
\end{tabular}

Pada Tabel 8. dapat dilihat bahwa nilai Signifikansi dari variabel budaya organisasi sebesar 0,862, gaya kepemimpinan sebesar 0,101, dan lingkungan kerja fisik sebesar 0,467. Nilai tersebut lebih besar dari 0,05 yang berarti tidak terdapat pengaruh antara variabel bebas terhadap absolute residual. Dengan demikian, model yang dibuat tidak mengandung gejala heteroskedastisitas.

Perhitungan koefisien regresi linier berganda dilakukan dengan analisis regresi melalui software SPSS 18.0 for Windows, diperoleh hasil yang ditunjukan pada Tabel 8 .

Berdasarkan hasil analisis regresi linier berganda seperti yang disajikan pada Tabel 8. maka dapat dibuat persamaan regresi sebagai berikut: 


$$
Y=1,130+0,164 X_{1}+0,230 X_{2}+0,219 X_{3}
$$

Nilai koefisien regresi masing-masing variabel bebas memiliki nilai signifikansi uji t kurang dari 0,05. Hal ini menunjukkan bahwa semua variabel bebas memiliki pengaruh yang signifikan terhadap variabel terikat.

Tabel 9.

Hasil Analisis Regresi Linier Berganda

\begin{tabular}{|c|c|c|c|c|c|}
\hline \multirow[t]{2}{*}{ Model } & \multicolumn{2}{|c|}{$\begin{array}{l}\text { Unstandardized } \\
\text { Coefficients }\end{array}$} & \multirow{2}{*}{$\begin{array}{c}\text { Standardized } \\
\text { Coefficients } \\
\text { Beta } \\
\end{array}$} & \multirow[b]{2}{*}{$\mathbf{t}$} & \multirow[b]{2}{*}{ Sig. } \\
\hline & B & Std. Error & & & \\
\hline (Constant) & 1.130 & 1.793 & & .630 & .533 \\
\hline Budaya organisasi & .164 & .066 & .309 & 2.463 & .019 \\
\hline Gaya kepemimpinan & .230 & .088 & .300 & 2.599 & .014 \\
\hline Lingkungan kerja fisik & .219 & .070 & .385 & 3.138 & .003 \\
\hline
\end{tabular}

Sumber :Data diolah, 2018

Koefisien determinasi (R2) digunakan untuk mengetahui dan mengukur kemampuan model dalam menerangkan variasi variabel independen. Peneliti menggunakan nilai adjusted R2 pada saat mengevaluasi yang mana model regresi terbaik, karena tidak seperti R2, nilai adjusted R2 dapat naik atau turun apabila satu variabel independen ditambahkan ke dalam model.

Tabel 10.

Hasil Uji Koefisien Determinasi $\left(\mathbf{R}^{2}\right)$

\begin{tabular}{lcccc}
\hline Model & $\mathbf{R}$ & R Square & Adjusted R Square & $\begin{array}{c}\text { Std. Error of the } \\
\text { Estimate }\end{array}$ \\
\hline 1 & $0,818^{\mathrm{a}}$ & 0,670 & 0,642 & 1,511 \\
\hline Sumber $:$ Data diolah, 2018 & & &
\end{tabular}

Hasil uji pada Tabel 10. memberikan hasil dimana diperoleh besarnya adjusted $\mathrm{R}^{2}$ (koefisien determinasi yang telah disesuaikan) adalah sebesar 0,642. Ini berarti variasi disiplin kerja karyawan pada UPT. BLK Industri dan Pariwisata Balidapat dipengaruhi secara signifikan oleh variabel budaya organisasi, gaya kepemimpinan dan lingkungan kerja fisik sebesar 64,2 persen, sedangkan sisanya 
sebesar 35,8 persen dijelaskan oleh faktor-faktor lain yang tidak dijelaskan dalam model penelitian.

Uji simultan bertujuan untuk mengetahui apakah semua variabel bebas yang diidentifikasi (budaya organisasi, gaya kepemimpinan, dan lingkungan kerja fisik) tepat digunakan memprediksi disiplin kerja secara bersama-sama. Uji ini sering juga disebut dengan uji F yang dapat dilihat pada Tabel 10. berikut :

Tabel 11.

Hasil Uji Simultan

\begin{tabular}{llrrrrr}
\hline Model & & Sum of Squares & Df & Mean Square & F & Sig. \\
\hline 1 & Regression & 162,108 & 3 & 54,036 & 23,673 & $0,000^{\mathrm{a}}$ \\
& Residual & 79,892 & 35 & 2,283 & & \\
& Total & 242,000 & 38 & & & \\
\hline
\end{tabular}

Sumber :Data diolah, 2018

Hasil uji $\mathrm{F}$ (F-test) pada Tabel 11 . menunjukkan bahwa nilai signifikansi $\mathrm{P}$ value 0,000 yang lebih kecil dari $\alpha=0,05$, ini berarti model yang digunakan pada penelitian ini adalah layak. Hasil ini memberikan makna bahwa seluruh variabel independen yang terdiri dari budaya organisasi, gaya kepemimpinan, dan lingkungan kerja fisik mampu memprediksi atau menjelaskan fenomena disiplin kerja karyawan pada UPT. BLK Industri dan Pariwisata Bali dengan kata lain ada pengaruh secara simultan dari variabel budaya organisasi, gaya kepemimpinan dan lingkungan kerja fisik terhadap disiplin kerja karyawan pada UPT. BLK Industri dan Pariwisata Bali. Hal ini berarti model dapat digunakan untuk analisa lebih lanjut atau dengan kata lain model dapat digunakan untuk memproyeksikan karena hasil goodness of fitnya baik dengan nilai signifikansi P value 0,000.

Berdasarkan hasil analisis pengaruh budaya organisasi terhadap disiplin kerja karyawandiperoleh nilai signifikasi sebesar 0,019 dengan nilai koefisien beta 
0,164. Nilai Signifikansi 0,019<0,05 mengindikasikan bahwa $\mathrm{H}_{0}$ ditolak dan $\mathrm{H}_{1}$ diterima. Hasil ini mempunyai arti bahwa budaya organisasi berpengaruh positif dan signifikan terhadap disiplin kerja karyawanpada UPT. BLK Industri dan Pariwisata Bali.

Berdasarkan hasil analisis pengaruh gaya kepemimpinan terhadap disiplin kerja karyawandiperoleh nilai signifikansi sebesar 0,014 dengan nilai koefisien beta 0,230 . Nilai Signifikansi $0,014<0,05$ mengindikasikan bahwa $\mathrm{H}_{0}$ ditolak dan $\mathrm{H}_{2}$ diterima. Hasil ini mempunyai arti bahwa gaya kepemimpinanberpengaruh positif dan signifikan terhadap disiplin kerja karyawanpada UPT. BLK Industri dan Pariwisata Bali. Artinya semakin baik gaya kepemimpinan pada UPT. BLK Industri dan Pariwisata Bali, maka akan membuat disiplin kerja karyawan semakin meningkat.

Berdasarkan hasil analisis pengaruh lingkungan kerja fisik terhadap disiplin kerja karyawandiperoleh nilai signifikansi sebesar 0,003 dengan nilai koefisien beta 0,219 . Nilai Signifikansi $0,003<0,05$ mengindikasikan bahwa $\mathrm{H}_{0}$ ditolak dan $\mathrm{H}_{3}$ diterima. Hasil ini mempunyai arti bahwa Lingkungan kerja fisikberpengaruh positif dan signifikan terhadap disiplin kerja karyawanpada UPT. BLK Industri dan Pariwisata Bali. Artinya semakin baik lingkungan kerja fisik pada UPT. BLK Industri dan Pariwisata Bali, maka akan membuat disiplin kerja karyawan semakin meningkat.

Hasil analisis menunjukkan bahwabudaya organisasiberpengaruh positif dan signifikan terhadap disiplin kerja karyawanpada UPT. BLK Industri dan Pariwisata Bali. Hasil ini mempunyai arti bahwa semakin kuat budaya organisasi 
pada UPT. BLK Industri dan Pariwisata Bali, maka disiplin kerja yang terbentuk pada karyawan akan semakin meningkat.Begitu pula sebaliknya, semakin lemah budaya organisasipada UPT. Balai Latihan Kerja Industri dan Pariwisata Balimaka akan berpengaruh pada semakin berkurangnya disiplin kerja karyawan.

Hasil tersebut mengindikasikan bahwa nilai - nilai yang terkandung dalam budaya organisasi mampu dipersepsikan dengan baik dan berdampak nyata terhadap disiplin kerja karyawan UPT. Balai Latihan Kerja Industri dan Pariwisata Bali. Budaya organisasi yang diukur berdasarkan indikator: ketepatan waktu kerja, kerapian berpakaian, kepatuhan pada aturan perusahaan, dan tanggung jawab, terbukti mampu meningkatkan disiplin kerja karyawan UPT. Balai Latihan Kerja Industri dan Pariwisata Bali. Temuan ini dapat diartikan bahwa apabilaUPT. Balai Latihan Kerja Industri dan Pariwisata Balimampu memperkuat budaya organisasi yang tegas, maka hal tersebut mampu memberikan kontribusi yang signifikan untuk meningkatkan disiplin kerja karyawan.

Terciptanya budaya organisasi yang kuat tentu dapat membentuk disiplin kerja yang tinggi pada karyawan, karena budaya organisasi yang kuat dapat mendorong anggota organisasi untuk berkomitmen dalam memajukan organisasi. Hal ini sejalan dengan penelitian yang dilakukan Suniastuti dan Suana (2012) yang menunjukkan hasil bahwabudaya organisasi berpengaruh positif dan signifikan terhadap disiplin kerja. Hasil penelitian ini juga didukung oleh hasil penelitian Iswara dan Sudharma (2013) serta Hadyan dan Lies Endarwati (2016) yang menemukan bahwa terdapat pengaruh signifikan budaya organisasi terhadap tingkat disiplin kerja. Hal ini berarti budaya organisasi dapat dijadikan pedoman 
untuk meningkatkan disiplin kerja di perusahaan tersebut, sehingga untuk mempertahankan disiplin kerja yang tinggi maka budaya organisasi harus lebih diperkuat.

Hasil analisis menunjukkan bahwagaya kepemimpinanberpengaruh positif dan signifikan terhadap kepuasan kerja.Hal ini berarti bahwa semakin baikdan tegas penerapan gaya kepemimpinan maka akan berpengaruh pada semakin meningkatnya disiplin kerja karyawan UPT. Balai Latihan Kerja Industri dan Pariwisata Bali. Begitu pula sebaliknya, semakin burukpenerapangaya kepemimpinanpada UPT. Balai Latihan Kerja Industri dan Pariwisata Balimaka akan berpengaruh pada semakin berkurangnya disiplin kerja karyawan.

Pembentukan disiplin kerja tentunya tidak terlepas dari peran seorang pemimpin dalam mengatur kebijakan yang terstruktur dalam organisasi. Gaya kepemimpinan yang efektif sebagai suatu bentuk pencapaian aturan kondisi kerja yang optimal untuk pencapaian tujuan perseorangan maupun tujuan organisasi sehingga dapat menimbulkan disiplin kerja yang besar kepada setiap karyawan.Hasil tersebut mengindikasikan bahwa nilai - nilai yang terkandung dalam gaya kepemimpinan mampu dipersepsikan dengan baik dan berdampak nyata terhadap disiplin kerja karyawan UPT. Balai Latihan Kerja Industri dan Pariwisata Bali. Gaya kepemimpinan yang diukur berdasarkan indikator: perilaku instruktif, perilaku konsultatif, perilaku partisipatif, perilaku delegatif, dan kepemimpinan suportifterbukti mampu meningkatkan disiplin kerja karyawan UPT. Balai Latihan Kerja Industri dan Pariwisata Bali. Temuan ini dapat diartikan bahwa apabilaUPT. Balai Latihan Kerja Industri dan Pariwisata Bali mampu 
meningkatkan penerapan gaya kepemimpinan yang baik dan tegas, maka hal tersebut mampu memberikan kontribusi yang signifikan untuk meningkatkan disiplin kerja karyawan.

Penelitian ini sesuai dengan hasil penelitian yang dilakukan olehBeverly et al. (2008) yang menunjukkan bahwa gaya kepemimpianan berpengaruh signifikan terhadap disiplin kerja karyawan yaitu keterlibatan pemimpin dalam berkreatifitas dapat meningkatkan aturan standar kerja karyawannya. Hasil penelitian ini juga di dukung oleh penelitian Ancok (2005), Suniastuti dan Suana, (2012), Susanty dan Baskoro, Sigit Wahyu (2012), Iswara dan Sudharma (2013), Ramli (2013), Sutarmaningtyas (2014), Cahyantara dan Subudi, (2015), Jaya dan Adnyani, (2015), serta Sugiyatmi dkk. (2016) yang memperoleh hasil bahwa ada pengaruh yang positif dan signifikan antara gaya gaya kepemimpinan terhadap disiplin kerja karyawan yang berarti bimbingan dari pimpinan akan mampu meningkatkan tujuan organisasi dan dapat meningkatkan evektifitas kerja karyawan.

Hasil analisis menunjukkan bahwa lingkungan kerja fisikberpengaruh positif dan signifikan terhadap disiplin kerja. Hal ini memiliki makna bahwa semakin baik lingkungan kerja fisik di UPT. Balai Latihan Kerja Industri dan Pariwisata Bali, maka akan semakin tinggi pula disiplin kerja yang terbentuk pada karyawan. Begitu pula sebaliknya, semakin buruk lingkungan kerja fisik di UPT. Balai Latihan Kerja Industri dan Pariwisata Bali maka semakin rendah tingkat disiplin kerjayang terbentuk pada karyawan UPT. Balai Latihan Kerja Industri dan Pariwisata Bali. 
Hasil tersebut mengindikasikan bahwa nilai - nilai yang terkandung dalam lingkungan kerja mampu dipersepsikan dengan baik dan berdampak nyata terhadap disiplin kerja karyawan UPT. Balai Latihan Kerja Industri dan Pariwisata Bali. Lingkungan kerja yang diukur berdasarkan indikator: penerangan, suhu dan udara, penggunaan warna, suara dalam ruangan kerja, kebersihan, ruang gerak dan keamananterbukti mampu meningkatkan disiplin kerja karyawan UPT. Balai Latihan Kerja Industri dan Pariwisata Bali. Temuan ini dapat diartikan bahwa apabilaUPT. Balai Latihan Kerja Industri dan Pariwisata Balimampu meningkatkan lingkungan kerja fisik, maka hal tersebut mampu memberikan kontribusi yang signifikan untuk meningkatkan disiplin kerja karyawan.

Hasil penelitian ini sesuai dengan hasil penelitian Khuong dan Le Vu (2014) yang menemukan bahwa karyawan yang merasa nyaman tentang lingkungan kerja mereka cenderung bekerja lebih efektif, disiplin dan menikmati proses kerja dibandingkan dengan mereka yang merasa tidak nyaman. Hasil penelitian ini juga mendukung temuan penelitian Martoyono (2009), Hernandez et al. (2011), Andriani (2010), Iswara dan Sudharma, (2013), Endriawan (2014), Marwanto dan Riyadi Nugroho (2014), serta Sugiyatmidkk. (2016) yang menemukan hasil bahwa lingkungan kerja fisik berpengaruh positif dan signifikan pada disiplin kerja karyawan yang berarti semakin baik kondisi lingkungan kerja maka akan berpengaruh pada semakin meningkatnya disiplin kerjakaryawan.

Penelitian ini menghasilkan simpulan mengenai pengaruh budaya organisasi, gaya kepemimpinan dan lingkungan kerja fisik pada disiplin kerja karyawan UPT. Balai Latihan Kerja Industri dan Pariwisata Bali. Hasil penelitian 
ini dapat berkontribusi memperluas pengetahuan dan wawasan serta informasi yang berkaitan denganbudaya organisasi, gaya kepemimpinan dan lingkungan kerja fisik pada disiplin kerja.

Penelitian ini diharapkan akan memberikan kontribusi positif bagi semua pihak khususnya UPT. Balai Latihan Kerja Industri dan Pariwisata Bali dalam meningkatkan disiplin kerja karyawan. Penelitian ini juga menjelaskan bahwa penerapan budaya organisasi yang kuat, lalu penerapan gaya kepemimpinan yang tegasdan tersedianya lingkungan kerja fisik sedemikian rupa yang baik sehingga terciptanya kenyamanan bekerja pada karyawan dan pada akhirnya dapat meningkatkan disiplin kerja pada lembaga yang terkait.

\section{SIMPULAN DAN SARAN}

Terdapat pengaruh positif dan signifikan antara variabel budaya organisasi terhadap disiplin kerja karyawan UPT. BLK Industri dan Pariwisata Bali. Terdapat pengaruh positif dan signifikan antara variabel gaya kepemimpinan terhadap disiplin kerja karyawan UPT. BLK Industri dan Pariwisata Bali.Terdapat pengaruh positif dan signifikan antara variabel lingkungan kerja fisik terhadap disiplin kerja karyawan UPT. BLK Industri dan Pariwisata Bali.

Saran secara teoritis untuk meningkatkan disiplin kerja, hal yang harus diperhatikan adalah budaya organisasi, gaya kepemimpinan, dan lingkungan kerja fisik.Saran secara praktis terhadap UPT. BLK Industri dan Pariwisata Bali untuk meningkatkan disiplin kerja dari karyawannya adalah dengan memperhatikan peran pimpinan (kepemimpinan untuk mempengaruhi orang lain agar orang tersebut bersedia secara ikhlas melaksanakan suatu pekerjaan dalam mencapai 
tujuan yang telah ditetapkan sebelumnya), budaya organisasi (budaya organisasi yang diterapkan dalam instansi), dan lingkungan kerja fisik (faktor fisik ini mencakup peralatan kerja, suhu, tempat kerja, kesesakan dan kepadatan, kebisingan, luas ruang kerja). Karena hal tersebut dapat meningkatkan disiplin kerja dari karyawan itu sendiri.

Saran bagi penelitian selanjutnya, penelitian ini hanya sebatas meneliti mengenai budaya organisasi, gaya kepemimpinan, dan lingkungan kerja fisik terhadap disiplin kerja. Peneliti selanjutnya diharapkan untuk menambah variabel lain, seperti: motivasi, pemberdayaan karyawan, kompensasi, dan komitmen organisasi, karena penelitian ini hanya memandang disiplin kerja karyawan yang dipengaruhi oleh budaya organisasi, gaya kepemimpinan, dan lingkungan kerja fisik. Peneliti selanjutnya juga diharapkan untuk dapat menggunakan alat analisis lainnya serta mengambil sampel diluar lingkungan instansi pemerintah, seperti: industri perhotelan, UMKM, dan lembaga keuangan.

\section{REFERENSI}

Ancok, Jamaludin. (2005). Hubungan Kepemimpinan Transformasional dan Transaksional dengan Motivasi Bawahan. Jurnal Psikologi, 32(2): 112-127.

Beverly Alimo., John Alban., Jeevi Martissan., and Chara Samele. (2008). Impact of Engaging Leadership on Performance, Attitudes to Work and Wellbeing at Work. Journal of Health Organization and Management, 22(6): 586-598.

Brahmasari, I. A., dan Siregar, P.(2009). Pengaruh Budaya Organisasi, Kepemimpinan Situasional dan Pola Komunikasi Terhadap Disiplin Kerja dan Kinerja Karyawan pada PT Central Proteinaprima TBK. Jurnal Aplikasi Manajemen, 7(1),238-250.

Cahyantara, I Putu Agus Eka., dan Made Subudi. (2015). Pengaruh Gaya Kepemimpinan Partisipatif dan Budaya Kerja terhadap Disiplin Kerja Karyawan dan Produktivitas Kerja Karyawan pada PT. PLN (Persero) Distribusi Bali, Area Bali Selatan. Jurnal Manajemen, 4(7): 2016-2035.

Daft, R. L. (2010). Management, 9th Edition. Ohio: Cancage Learning. 
Dhermawan, Anak Agung Ngurah Bagus, dkk. (2012). Pengaruh Motivasi, Lingkungan Kerja, Kompetensi dan Kompensasi Terhadap Kepuasan Kerja dan Kinerja Karyawan di Lingkungan Kantor Dinas Pekerjaan Umum Provinsi Bali.Jurnal Manajemen, Strategi Bisnis dan Kewirausahaan, Vol. 6.

Endriawan, Billy Dwi Agista. (2014). Analisis Pengaruh Gaya Kepemimpinan Transformasionaldan Lingkungan Non Fisik terhadap Disiplin Kerja Karyawan (Studi pada Dinas Pekerjaan Umum Kota Tangerang Bidang Sumber Daya Air). Skripsi. Fakultas Ekonomi dan Bisnis Universitas Diponegoro, Semarang.

Hasibuan, Malayu S.P. (2009). Manajemen Dasar, Pengertian, Dan Masalah. Jakarta: PT Bumi Aksara.

Hernandez, Morela, Eberly, Marion B., Avolio, Bruce J., Johnson, Michael D.,( 2011), The loci and mechanisms of leadership: Exploring a more comprehensive view of leadership theory, The Leadership Quarterly 22, pp. $1165-1185$.

Hesselbein, F., and Cohen, P. M. (1999). The shape of things to come. Leader to Leader: Enduring Insights on Leadership from the Drucker Foundation's Award-Winning Journal (1st ed., pp. 109-120). San Francisco: John Wiley dan Sons.

Iswara, I GustiAgung Rama Pramudita dan I Nyoman Sudharma. (2013). Pengaruh Gaya Kepemimpinan, Budaya Organisasi dan Lingkungan Kera Fisik terhadap Disiplin Kerja Karyawan di Dinas Pertanian Tanaman Pangan dan Hortikultura Kota Denpasar.Jurnal Manajemen, 2 (6), hal: 671682

Jaya, Kadek Yudi Prawira., dan I Gusti Ayu Dewi Adnyani. (2015). Pengaruh Gaya Kepemimpinan terhadap Disiplin Kerja Karyawan di Dinas Balai Bahasa Provinsi Bali. Jurnal Manajemen, 4(9): 2702-2721.

Kheruniah, AdeiEen. (2013). A Teacher Personality Competencei Contribution ToA Student Study Motivation and Dicipline To FiqhiLesson. International journal of Scientific dan Technology Research, 2(2).

Mahdi, Omar Rabeea, Erzan Shafizan Bin Gulam Mohd, and Mahmoud Khalid Almsafir. (2014). Empirical Study on the Impact of Leadership Behavior on Organizational Commitment in Plantation Companies in Malaysia. Journal of Business, Economics and Management, 109: 1076-1087.

Mohelska, H., and Sokolova, M. (2015). Organizational Culture and Leadership Joint Vessels ?Procedia: Social and Behavioral Sciences, 171: 1011-1016.

Martoyo, Susilo. (2002). Manajemen Sumber Daya manusia. Edisi Kedelapan. BPFE. Yogyakarta.

Martoyo, Susilo.( 2009). Manajemen Sumber Daya Manusia. Yogyakarta : BPFE. 
Marwanto, Tri Budi., dan Riyadi Nugroho. (2014). Pengaruh Kompensasi dan Lingkungan Kerja terhadap Motivasi dan Disiplin Kerja Prajurit di Satuan Kerja KRI X Armada RI Kawasan Timur. Jurnal Ilmu Ekonomi dan Manajemen, 1(1): 74-82.

Moorhead, Gregory, dan Griffin. (1995). Organizational Behavioral :Managing People and Organization. Fourth Edition. HoughtonMifflin Co.

Nugroho, Adi. (2009). Rekayasa Perangkat Lunak Menggunakan UML Dan Java. ANDI, Yogyakarta.

Parlinda, Vera dan Wahyudin, M, (2008). Pengaruh Kepemimpinan, Motivasi, Pelatihan dan Lingkungan Kerja Terhadap Kinerja Karyawan. Tesis, Studi Pada Karyawan Perusahaan Daerah Air Minum, Surakarta. http://eprints.dinus.ac.id/5077/1/11392.pdf. Diakses 05-10-2015. Hal.1.

Ramli, Soehatman. (2013). Sistem Manajemen Keselamatan dan Kesehatan Kerja OSHAS 18001. Jakarta: PT. Dian Rakyat.

Rivai, Veithzal, Deddy Mulyadi. (2009). Kepemimpinan dan Perilaku Organisasi. Edisi Ketiga. Jakarta: PT Raja Grafindo Persada.

Rivai, Veithzal. (2009). Manajemen Sumber Daya Manusia Untuk Perusahaan Dari Teori ke Praktik. Jakarta: Raja Grafindo Persada.

Robbins, S. P. (2010). Organizational Behavior, 15th Edition. New Jersey: Pearson Education, Inc.

Schein, E. H. (2004). Organizational Culture and Leadership, 3th Edition. San Francisco: John Wiley dan Sons, Inc.

Siagian, Pariang. (2011). Analisis Kinerja Keuangan Bank Danamon Periode 2006 hingga 2010. Jurnal Ekonomi. 21(2): h:138-150.

Stephen, Craig., and Barry Stemshorn. (2016). Leadership, Governance and Partnershipare Essential One Health Competencies. Jurnal of Health, 2: 161-163.

Sugiyatmi, Maria Magdalena., dan Edward Gagah PT. (2016). Pengaruh Motivasi, Gaya Kepemimpinan, dan Lingkungan Kerja Fisik terhadap Disiplin Kerja serta Dampaknya terhadap Kinerja Karyawan di PT. Bina San Prima. Jurnal Manajemen, 2(2), ISSN: 2502-7689.

Suniastuti, Ni PutuEster dan I Wayan Suana. (2013). Pengaruh GayaKepemimpinan, Budaya Organisasi dan Komunikasi terhadap DisiplinKerja Karyawan Perusahaan Daerah Parkir Kota Denpasar.Jurnal Manajemen, 1 (1), hal: 90-109.

Sukma, Wati Ni Luh. (2013). Pengaruh Motivasi Non Finansial dan Lingkungan Kerja Fisik Terhadap Disiplin Kerja Karyawan Pada PT Indomobil Denpasar.Skirpsi. Fakultas Ekonomi Universitas Mahasaraswati Denpasar. 
E-Jurnal Manajemen, Vol. 8, No. 8, 2019 :5090-5117

Susanty, Aries., dan Sigit Wahyu Baskoro. (2012). Pengaruh Motivasi Kerja dan Gaya Kepemimpinan terhadap Disiplin Kerja serta Dampaknya pada Kinerja Karyawan (Studi Kasus pada PT. PLN (Persero) APD Semarang). Jurnal Teknik Industri, 7(2).

Sutarmaningtyas, Ari Nurul. (2014). Pengaruh Gaya Kepemimpinan Transformasional dan Transaksional Terhadap Disiplin Kerja Karyawan. Jurnal Administrasi Bisnis. Vol. 14 No.2

Thoha, Miftah. (2010). Kepemimpinan dalam Manajemen Suatu Pendekatan Perilaku. Cetakan Kesembilan. Jakarta: PT. Raja Grafindo Persada.

Yukl, Garry, (2010), Kepemimpinan dalam Organisasi, Edisi Kelima, Jakarta: PT. Indeks. 